\title{
Depolarization-Induced Neurite Outgrowth in PC12 Cells Requires Permissive, Low Level NGF Receptor Stimulation and Activation of Calcium/Calmodulin-Dependent Protein Kinase
}

\author{
Michele Solem, Thomas McMahon, and Robert O. Messing \\ Ernest Gallo Clinic and Research Center, Department of Neurology, University of California, San Francisco, \\ California 94110
}

\begin{abstract}
Neuronal activity is required for normal neural development. Excessive activity can cause abnormal growth of neural processes and may contribute to formation of epileptic foci. Using PC12 cells, we investigated mechanisms by which depolarization regulates neurite growth. Depolarization with $45 \mathrm{~mm} \mathrm{KCl}$ induced neurite outgrowth only if NGF receptors were partly activated by overexpression of p140 trka or by treatment with a low concentration of NGF that alone was insufficient to stimulate neurite formation. Depolarization-induced neurite growth was reduced by inhibitors of L-type $\mathrm{Ca}^{2+}$ channels, $\mathrm{Ca}^{2+} /$ calmodulln-dependent protein (CaM) kinases II and IV, and transcription. These results identify a novel mechanism by which depolarizing stimuli synergize with subthreshold activation of NGF receptors to induce neurite growth through $\mathrm{a} \mathrm{Ca}^{2+}$ and CaM kinase-dependent signal transduction pathway.

[Key words: PC12 cells, neurite outgrowth, NGF, depolarization, L channel, calcium channel, calcium/calmodulindependent protein kinase]
\end{abstract}

Normal neuronal activity regulates neural development and plasticity (Goodman and Shatz, 1993). Excessive activity during seizures can cause aberrant growth of neural processes which may contribute to the development of epileptic foci (McNamara, 1994). Neuronal activity elevates the concentration of intracellular $\mathrm{Ca}^{2+}\left(\left[\mathrm{Ca}^{2+}{ }_{i}\right]\right)$ by opening voltage- or receptor-gated ion channels, or by stimulating release of $\mathrm{Ca}^{2+}$ from internal stores (Mayer and Miller, 1990; Berridge, 1993; Hofmann et al., 1994). Increases in $\left[\mathrm{Ca}^{2+}\right]_{i}$ modulate neural growth and differentiation (Kater and Mills, 1991). Although in some neurons, elevation of $\left[\mathrm{Ca}^{2+}\right]_{i}$ inhibits neurite growth (Baker ct al., 1991; Cohan, 1992; Bandtlow et al., 1993; Bär et al., 1993), in others, it stimulates growth of neurites (Nishi and Berg, 1981; Anglister et al., 1982; Unsicker et al., 1983; Rogers and Hendry, 1990), and growth cones (Anglister et al., 1982; Adams and Gullick, 1989; Silver et al., 1990; Zheng et al., 1994). There appears to be an optimal level of $\left[\mathrm{Ca}^{2+}\right]_{i}$ for neurite outgrowth, and concentra-

\footnotetext{
Received Mar. 7, 1995; accepted Apr. 21, 1995.

We thank A. Gordon and U. Heberlein for thoughtful discussions and A. Gordon, I. Diamond, and D. Lowenstein for critical reading of the manuscript. This work was supported in part by grants from the National Institute on AIcohol Abuse and Alcoholism and from the Alcoholic Beverage Medical Research Foundation to R.O.M.

Correspondence should be addressed to Robert O. Messing, M.D., Building 1, Room 101, 1001 Potrero Avenue, San Francisco, CA 94110.

Copyright 1995 Society for Neuroscience $0270-6474 / 95 / 155966-10 \$ 05.00 / 0$
}

tions below or above this level inhibit growth (Lankford and Letourneau, 1991).

Elevations in $\left[\mathrm{Ca}^{2+}\right]_{i}$ can stimulate neurite growth by upregulating neurotrophic factors or their receptors. In cultured rat cortical neurons, depolarization increases BDNF expression, and enhances neurite outgrowth by a BDNF-dependent mechanism (Ghosh et al., 1994). This is prevented by chelating external $\mathrm{Ca}^{2+}$ or by blocking L-type voltage-gated $\mathrm{Ca}^{2+}$ channels, indicating that $\mathrm{Ca}^{2+}$ influx through $\mathrm{L}$ channels stimulates BDNF expression in these cultures. On the other hand, in the sympathoadrenal cell line MAH, depolarization stimulates expression of p140 trkA, the NGF tyrosine kinase receptor, enabling cells to undergo NGF-stimulated neurite outgrowth (Birren et al., 1992). The L channel agonist Bay K 8644 enhances expression of p140 rrka stimulated by a low concentration ( $20 \mathrm{mM}$ ) of $\mathrm{KCl}$, indicating that $\mathrm{Ca}^{2+}$ influx through $\mathrm{L}$ channels is involved in the induction of p140 $10^{\text {trka }}$. In contrast, however, PC1 2 cells, which undergo NGF-induced neuronal differentiation, extend neurites in the absence of NGF when they are cultured on monolayers of fibroblasts and depolarized with $\mathrm{KCl}$ (Saffell ct al., 1992). This response is blocked by $\mathrm{L}$ channel antagonists, suggesting that growth factor-independent mechanisms stimulated by $\mathrm{Ca}^{2+}$ influx can also mediate depolarization-induced neurite outgrowth.

We recently found that depolarization induced neurite outgrowth in $\mathrm{PC} 12$ clones that overexpress the NGF receptor tyrosine kinase, p140 ${ }^{t / k A}$. Compared to wild-type PC12 cells, these trk-PC12 clones exhibit a low level of NGF receptor activation in the absence of added NGF and undergo rapid NGF-induced differentiation (Hempstead et al., 1992). In contrast, depolarization did not stimulate neurite outgrowth from wild-type $\mathrm{PC} 12$ cells cultured on collagen or polyornithine, which is in agreement with findings of others (Greene et al., 1982). We undertook the following study to investigate why trk-PC12 cells are uniquely able to undergo depolarization-induced neurite outgrowth. Our findings indicate that low levels of NGF receptor activation, insufficient to induce morphological differentiation alone, can sensitize cells to differentiate by a depolarizationactivated pathway involving $\mathrm{L}$ channels and $\mathrm{Ca}^{2+} /$ calmodulindependent protein kinase.

\section{Materials and Methods}

Materials. trk- $\mathrm{PCl} 2$ clones 6-15 and 6-24, which overexpress p140'rkA, (Hempstead et al., 1992) were gifts from David R. Kaplan (Frederick Cancer Center, Frederick, MD). The parent PC12 cell line was obtained from Regis Kelly (University of California, San Francisco). NGF (2.5S) was a gift from William Mobley (University of California, San Fran- 
cisco). Anti-GAP-43 antibody (clone 91E12), goat anti-mouse IgG antibody-peroxidase conjugate, goat anti-mouse IgG antibody-FITC conjugate, and laminin were purchased from Boehringer Mannheim (Indianapolis, IN). Collagen was from Collaborative Biomedical Products (Bedford, MA). Bisindolylmaleimide was from Calbiochem (La Jolla, CA). Poly-L- ornithine, nifedipine, mecamylamine, ethosuximide, tetrodotoxin, verapamil, leupeptin, aprotonin, soybean trypsin inhibitor, and phenymethylsulfonyl fluoride were purchased from Sigma (St. Louis, MO). $\omega$ - Conotoxin GVIA was from Peptides International (Louisville, $\mathrm{KY}$ ) and $\omega$ - agatoxin GIVA was a gift from Michael Adams (University of California, Riverside). Fura-2 acetomethoxy ester was from Molecular Probes (Eugene, OR). KN-62 was from Seikagaku America (Rockville, MD) and was dissolved in dimethyl sulfoxide at $10 \mathrm{~mm}$. K252b was from Calbiochem (La Jolla, CA) and was dissolved in dimethyl sulfoxide at $1 \mathrm{~mm}$. Therefore, cultures treated with the highest concentrations of $\mathrm{KN}-62$ or $\mathrm{K} 252 \mathrm{~b}$ used in these studies were exposed to $0.1 \%$ dimethyl sulfoxide $(\mathrm{vol} / \mathrm{vol})$. This concentration of dimethyl sulfoxide alone did not alter $\mathrm{K}^{+}$-stimulated ${ }^{45} \mathrm{Ca}^{2+}$ uptake or $\mathrm{K}^{+}$-induced neurite outgrowth in control cultures.

Cell culture. Cells were maintained in a humidified atmosphere of $90 \%$ air and $10 \% \mathrm{CO}_{2}$ at $37^{\circ} \mathrm{C}$ in conplete mediun consisting of Dulbecco's modified Eagle's medium (DMEM) supplemented with $10 \%$ heat-inactivated horse serum, $5 \%$ fetal calf serum, $2 \mathrm{~mm}$ glutamine, 50 $\mathrm{U} / \mathrm{ml}$ of penicillin, and $50 \mu \mathrm{g} / \mathrm{ml}$ of streptomycin. In some studies, cells were cultured in defined medium, as described previously (Messing et al., 1991).

Neurite outgrowth. Cells were plated on 24-well plates at a density of $5 \times 10^{4} /$ well. In most experiments plates were treated with $0.1 \mathrm{mg} / \mathrm{ml}$ of polyornithine or $20 \mu \mathrm{g} / \mathrm{ml}$ of laminin, or coated with $3 \mu \mathrm{g} / \mathrm{well}$ of collagen before plating of cells. Depolarization was achieved by adding $40 \mathrm{~mm} \mathrm{KCl}$ to the medium, yielding a final $\mathrm{KCl}$ concentration of 45 mM. To control for osmolarity, $40 \mathrm{~mm}$ choline chloride was added to control cultures. A neurite was defined as a process greater than one cell body in length and possessing a terminal growth cone. The percentage of cells with neurites was calculated by counting 100 cells per well in triplicate wells. The length of neurites was measured from 35 $\mathrm{mm}$ photomicrographs viewed through a slide viewer. Measurements were converted to $\mu \mathrm{m}$ using a micrometer photographed at the same magnification.

Immunofluorescence. Cells were plated on Lab-tek (Nunc, Naperville, IL) multichamber slides treated with $0.1 \mathrm{mg} / \mathrm{ml}$ of poly-D-lysine and 20 $\mu \mathrm{g} / \mathrm{ml}$ of laminin. After culture for $48 \mathrm{hr}$ in complete medium supplemented with $40 \mathrm{~mm} \mathrm{KCl}, 40 \mathrm{~mm}$ choline chloride, or 2 nM NGF, cells were fixed for $10 \mathrm{~min}$ in PBS containing $0.12 \mathrm{M}$ sucrose and $4 \%$ paraformaldehyde. Cells were rinsed twice with PBS and treated with $95 \%$ ethanol for $1 \mathrm{~min}$. After two washes in PBS, cells were blocked in PBS containing $2 \%$ bovine serum albumin (BSA) for $2 \mathrm{hr}$ at $37^{\circ} \mathrm{C}$ and then incubated with anti-GAP-43 antibody (diluted 1:2000 in PBS/1\% BSA) for $1 \mathrm{hr}$ at $37^{\circ} \mathrm{C}$ and then overnight at $4^{\circ} \mathrm{C}$. After three washes with PBS containing $0.1 \%$ Triton $\mathrm{X}-100$, cells were incubated in goat antimouse IgG antibody-FITC conjugate (1:600 in PBS) for $1 \mathrm{hr}$ at $37^{\circ} \mathrm{C}$, and then washed three times in PBS. Cells were viewed photographed at $400 \times$ magnification using a Leitz DMRB microscope.

Western analysis. Cells $\left(6 \times 10^{6}\right.$ cells $/$ dish $)$ were cultured on poly ornithine-treated $100 \mathrm{~mm}$ tissue culture dishes in complete medium supplemented with $40 \mathrm{~mm} \mathrm{KCl}, 40 \mathrm{~mm}$ choline chloride, or $2 \mathrm{nM}$ NGF for $1-2 \mathrm{~d}$. Dishes were then washed twice in ice-cold PSS $(120 \mathrm{NaCl}, 5$ $\mathrm{mm} \mathrm{KCl}, 1.4 \mathrm{~mm} \mathrm{CaCl}, 0.8 \mathrm{~mm} \mathrm{MgSO}, 1 \mathrm{~mm} \mathrm{NaH} \mathrm{PO}_{4}, 25 \mathrm{~mm}$ HEPES, $\mathrm{pH} 7.4$, and $10 \mathrm{~mm}$ glucose). Cells were scraped into PSS containing $1 \mathrm{~mm}$ phenymethylsulfonyl fluoride, and $40 \mu \mathrm{g} / \mathrm{ml}$ each of leupeptin, aprotonin, and soybean trypsin inhibitor. Samples of cell lysates containing 75 or $150 \mu \mathrm{g}$ were electrophoresed in $12 \%$ SDS-polyacrylamide gels and proteins were electrophoretically transferred to Hybond-C extra membranes. Membranes were blocked in TBS (20 mM Tris- $\mathrm{HCl}, \mathrm{pH} 7.4,137 \mathrm{~mm} \mathrm{NaCl}$ ) containing 5\% non-fat dry milk for 1 hr at room temperature and then washed three times with TBS containing $0.1 \%$ Tween-20. Blots were incubated with anti-GAP43 antibody diluted $1: 200$ in TBS containing $0.1 \%$ Tween-20 and $1 \%$ non-fat dry milk for $1 \mathrm{hr}$ at $37^{\circ} \mathrm{C}$ and then overnight at $4^{\circ} \mathrm{C}$. After three washes in TBS $/ 0.1 \%$ Tween- 20 , blots were incubated with anti-mouse IgG antibody-alkaline phosphatase conjugate (diluted $1: 3000$ in $\mathrm{IBS} / 0.1 \%$ Tween-20/1\% non-fat dry milk) for $1 \mathrm{hr}$ at room temperature. Blots were then washed three times in TBS/0.1\% Tween- 20 and immunoreactive bands were detected with the Bio-Rad Immunolite II detection system.
Calcium uptake. Depolarization-stimulated ${ }^{45} \mathrm{Ca}$ uptake was measured as described previously (Messing et al., 1990).

Calcium imaging. Cells were cultured for $24 \mathrm{hr}$ on $22 \mathrm{~mm}$ square glass coverslips treated with $0.1 \mathrm{mg} / \mathrm{ml}$ of poly-L-ornithine and 30 $\mu \mathrm{g} / \mathrm{ml}$ of laminin, in complete medium, or complete medium containing $45 \mathrm{mM} \mathrm{KCl}$, with or without $2 \mathrm{mM}$ EGTA. Coverslips were then incubated with $5 \mu \mathrm{M}$ fura-2AM for $30 \mathrm{~min}$ at $37^{\circ} \mathrm{C}$ in phenol red-free DMEM, in the continued presence or absence of $45 \mathrm{mM} \mathrm{KCl}$ and $2 \mathrm{mM}$ EGTA. Coverslips were mounted in a perfusion chamber (model RC21B, Warner Instruments, Handen, CT) and cells were gently perfused with fresh phenol red-free DMEM with or without $45 \mathrm{mM} \mathrm{KCl}$ and 2 mM EGTA. An Olympus IMT-2 inverted microscope fitted with a Nikon UV-F $40 \times$ oil immersion objective and a $150 \mathrm{~W}$ xenon lamp (Osram) was used for fluorescence measurements. Fluorescence emission intensities at $510 \mathrm{~nm}$ following paired excitation at $350 \mathrm{~nm}$ and $380 \mathrm{~nm}$ were detected using a liquid-cooled CCD camera (Photometrics Ltd., Tucson, AZ) fitted with a Thompson 7883 chip $(384 \times 576$ pixels $)$. Exposure times were 0.05 sec and $2 \times 2$ binning was used to shorten readout speed and enhance image intensity. Paired $350 \mathrm{~nm}$ and $380 \mathrm{~nm}$ images were separated by less than $0.3 \mathrm{sec}$, the time required to change excitation filters and readout the $\mathrm{CCD}$ chip. Intracellular $\mathrm{Ca}^{2+}$ concentra tions were calculated from the ratio of emission intensities at $350 \mathrm{~nm}$ and $380 \mathrm{~nm}$ (Grynkiewicz et al., 1985) after subtracting for background fluorescence in regions devoid of cells. The $K_{D}$ of fura-2 for $\mathrm{Ca}^{2+}$ was estimated to be $190 \mathrm{~nm}$ (Williams and Fay, 1990). The $R_{\max }$ was measured by incubating cells in $10 \mu \mathrm{M}$ 4-bromo-A23187, $10 \mu \mathrm{M}$ monensin, and $1.0 \mathrm{~mm}$ oubain. $R_{\min }$ was measured after adding $20 \mathrm{mM}$ EGTA, $\mathrm{pH}$ 8.7. Higher concentrations of EGTA produced no further decrease in $R_{\min }$. Background fluorescence in cells not loaded with fura-2 was less than $1 \%$ of fluorescence measured in cells loaded with fura- 2 .

\section{Results}

\section{$K^{+}$stimulates neurite outgrowth in PCI2 cells that overexpress $p 140^{\mathrm{trk} A}$}

When cultured in omplete medium alone, 5-7\% of trk-PC12 6-24 cells spontaneously expressed short processes, as reported previously (Hempstead et al., 1992). Treatment of these cells with $45 \mathrm{~mm} \mathrm{KCl}$ caused striking outgrowth of neurites (Fig. $1 \mathrm{C}-$ $E)$. The number of cells with neurites and the length of neurites was greater than neurite outgrowth observed in wild-type $\mathrm{PCl} 2$ cells treated with $2 \mathrm{nM}$ NGF for the same amount of time (Fig. $1 D, E$ ). As reported (Hempstead et al., 1992), trk-PC12 cells also rapidly grew neurites when exposed to $2 \mathrm{nM} \mathrm{NGF} \mathrm{(Fig.} \mathrm{1C-E).}$ In contrast to $\mathrm{KCl}$ or $\mathrm{NGF}, 40 \mathrm{~mm}$ choline chloride did not stimulate neurite outgrowth (Fig. 1A). The concentration dependence for $\mathrm{KCl}$-induced neurite outgrowth was biphasic and the percentage of trk-PC12 cells with neurites was maximal in 45 mM KCl (Fig. $1 F$ ). Similar results were obtained when cells were cultured on untreated plastic dishes, on dishes treated with laminin, collagen, or poly-D-lysine, or in defined medium. Another p140 rki -overexpressing clone, 6-15, also extended neurites when depolarized with $\mathrm{KCl}$ (data not shown). In contrast to trkPC12 cells, wild-type PCl2 cells showed very little response to $\mathrm{KCl}$ (Fig. $1 D)$, and even after $7 \mathrm{~d}$ in culture, only $17 \pm 1 \%(\mathrm{~N}$ $=2$ ) of cells cxtended short processes. Howcver, after $7 \mathrm{~d}$ in culture with $\mathrm{KCl}, 60 \pm 4 \%(N=2)$ of $t r k$-PC12 cells expressed neurites.

Depolarization-induced neurites were slightly thinner than NGF-induced neurites (Fig. $1 B, C$ ) but had well-defined growth cones and were immunoreactive for the growth cone associated protein GAP-43 (Fig. 2A-C). Western analysis revealed that $\mathrm{KCl}$ increased levels of GAP-43 immunoreactivity in 6-24 cells, although not to the same extent as levels achieved after treatment with 2 nM NGF (Fig. 2D).

\section{Role of NGF receptors in $\mathrm{K}^{+}$-induced neurite outgrowth}

The ability of $\mathrm{K}^{+}$to stimulate neurite outgrowth in $\mathrm{PCl} 2$ cells that overexpress $p 140^{i k A}$ suggested a role for NGF receptor ac- 

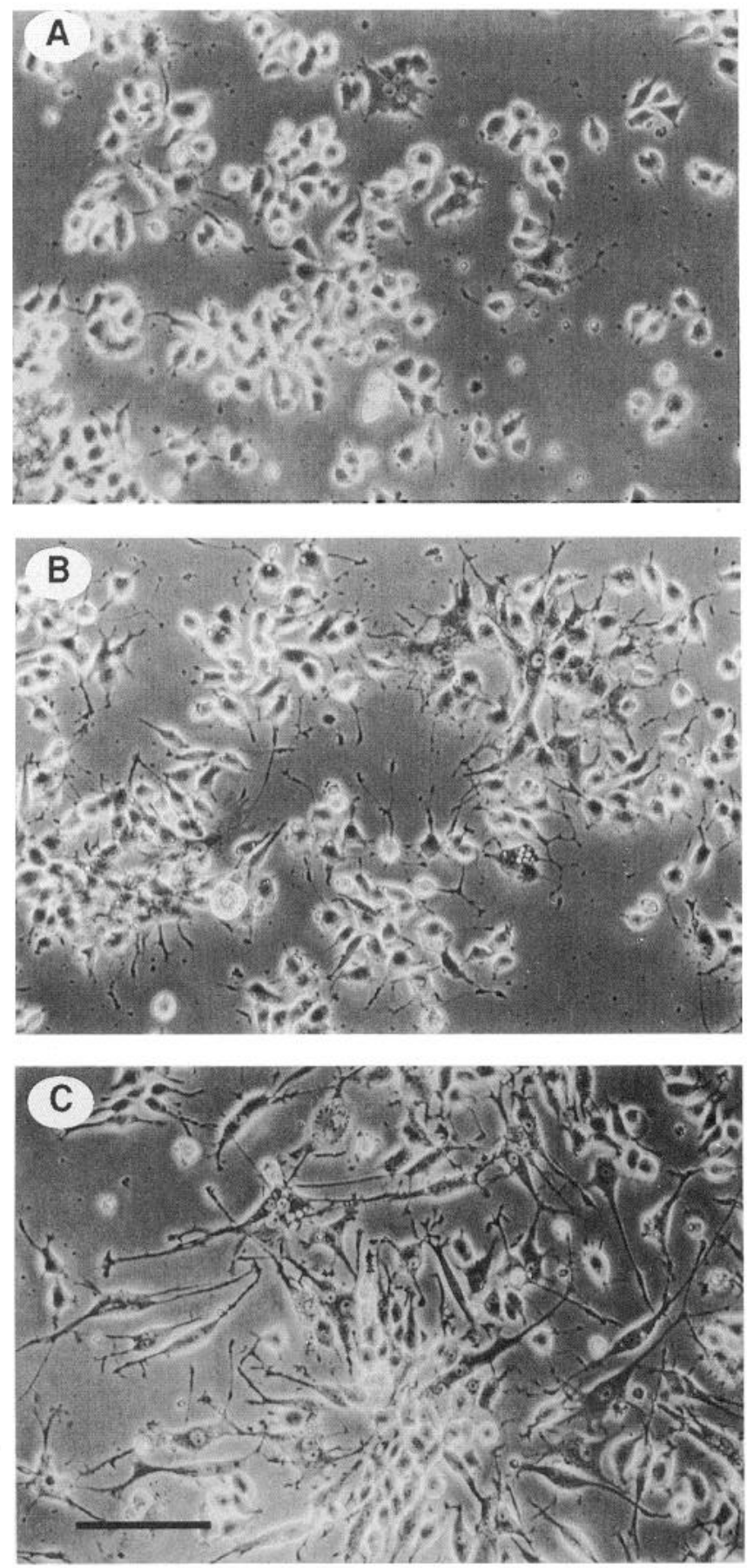
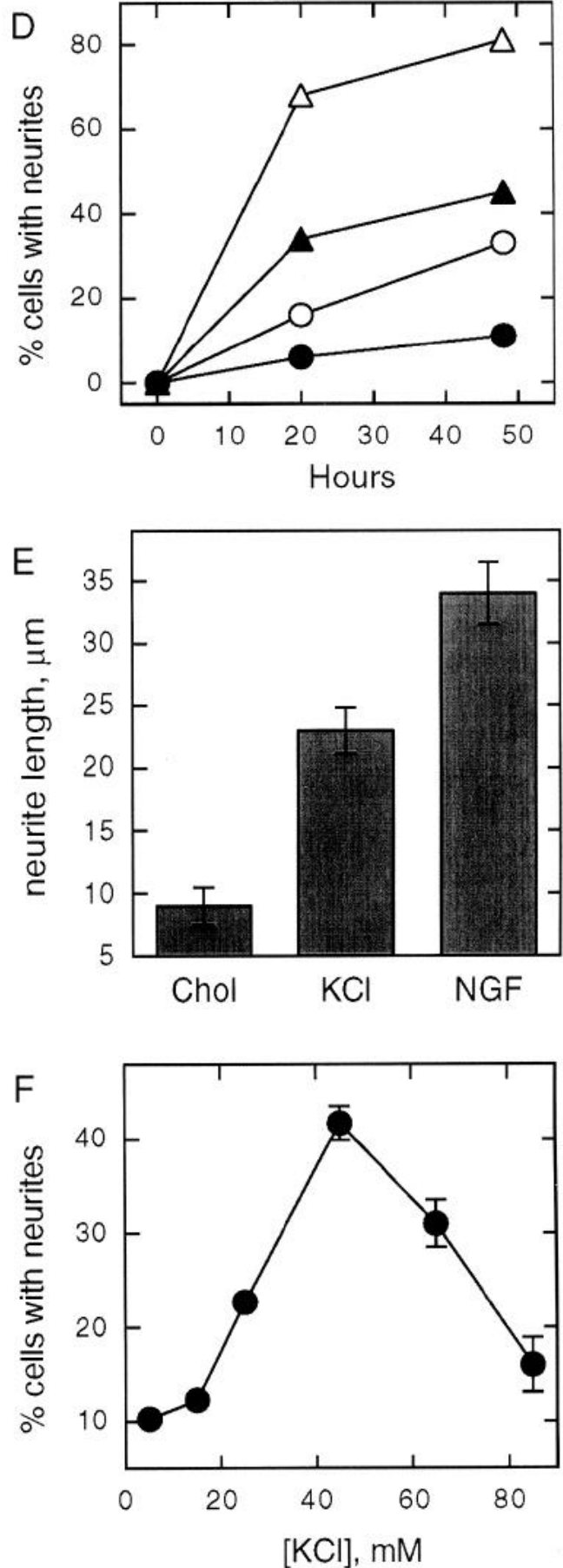

Figure 1. Comparison of $\mathrm{K}^{+}$- and NGF-induced neurite outgrowth in trk-PC12 and wild-type PC12 cells. Phase-contrast micrographs of trk-PC12 6-24 cells were taken after culture for $48 \mathrm{hr}$ on poly-L-ornithine-coated plates in complete medium containing $40 \mathrm{~mm}$ choline chloride $(A), 45 \mathrm{~mm}$ $\mathrm{KCl}(B)$, or $2 \mathrm{~nm} \mathrm{NGF}(C)$. Scale bar, $15 \mu \mathrm{m}$. $D$, The percentage of cells with neurites was measured in cultures of $t r k$-PC12 6-24 cells $(\triangle, \boldsymbol{\Delta})$ or of wild-type PC12 cells $(O, \boldsymbol{O})$ treated with $\operatorname{NGF}(\triangle, O)$ or $\mathrm{KCl}(\boldsymbol{\Delta}, \boldsymbol{O})$. Data are mean $\pm \mathrm{SE}$ values from three experiments. $E$, Neurite length was measured from photomicrographs of $t r k-\mathrm{PC} 126-24$ cells cultured for $2 \mathrm{~d}$ in indicated agents. Data are mean $\pm \mathrm{SE}$ values from 90-100 neurites for each condition in a single experiment, repeated once with similar results. $F$, The percentage of cells with neurites was measured in $t r k$-PC12 6-24 cells cultured for $24 \mathrm{hr}$ in $5-85 \mathrm{~mm} \mathrm{KCl}$, as indicated. Data are mean \pm SE values from three experiments. Error bars are omitted where they did not extend beyond the data symbols.

tivation in $\mathrm{K}^{+}$-induced neurite formation. One mechanism by which depolarization might induce neurite outgrowth is by activating NGF receptors. Binding of NGF to p140 $14 \times A$ stimulates dimerization and autophosphorylation of $\mathrm{p} 140^{\text {rrkA }}$ on tyrosine residues (Kaplan et al., 1991). This process stimulates a Ras-de- pendent signal transduction pathway leading to activation of $\mathrm{p} 44^{\text {mapk }}$ and $\mathrm{p} 42^{\text {mapk }}$ mitogen activated protein (MAP) kinases (also known as extracellular signal-regulated kinases ERK-1 and ERK-2) by phosphorylation on tyrosine and threonine residues (Boulton et al., 1991; Thomas et al., 1992; Wood et al., 1992). 

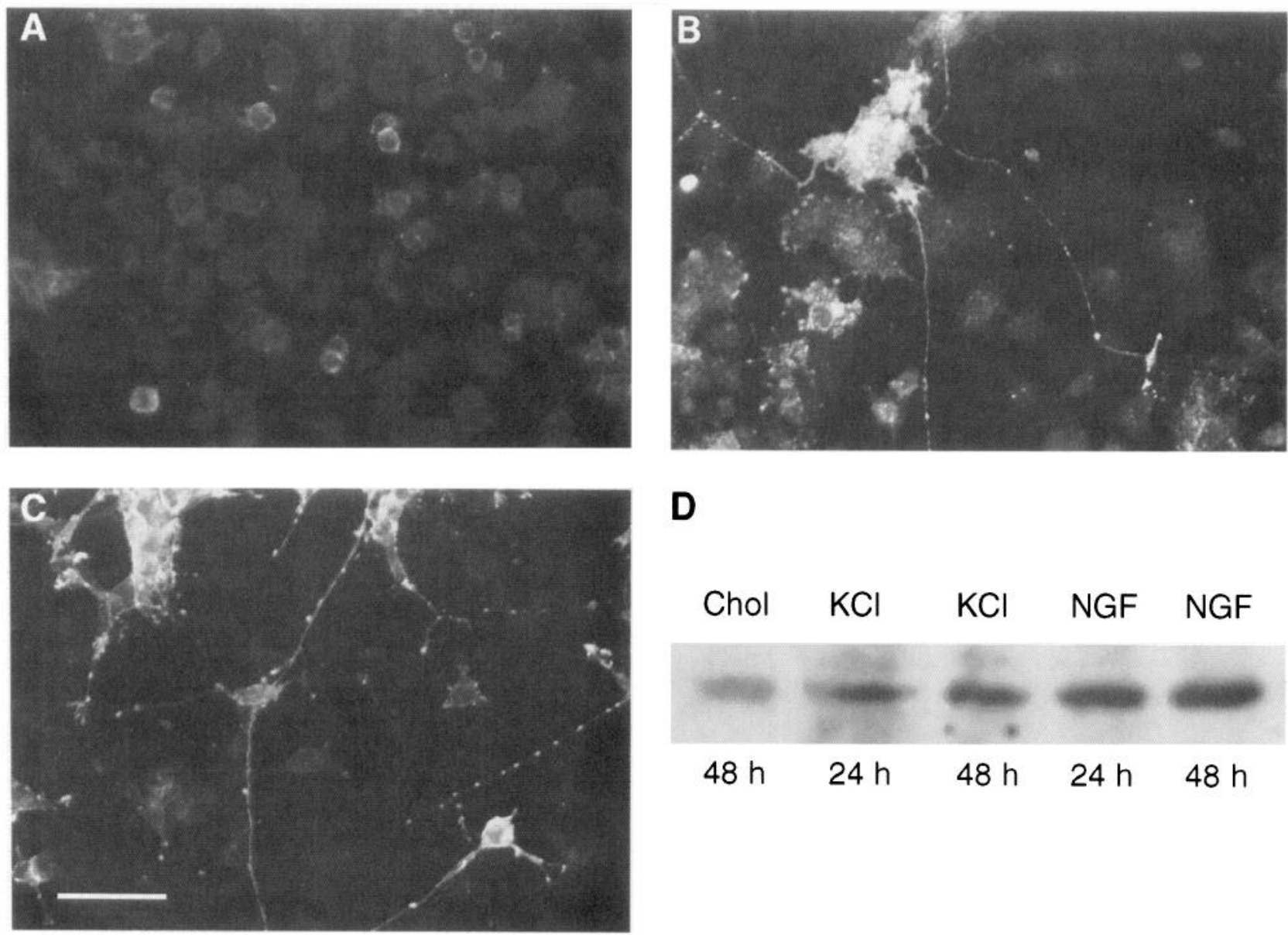

D

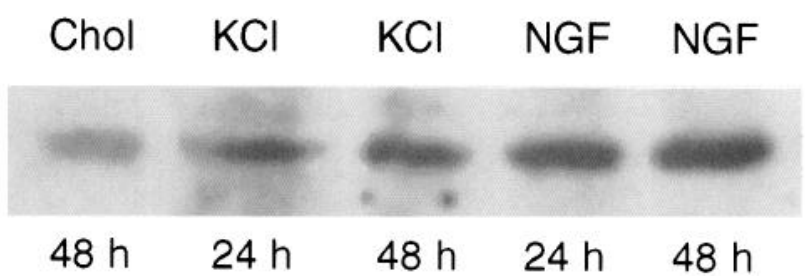

Figure 2. GAP-43 immunoreactivity in trk-PC12 6-24 cells cultured in $\mathrm{KCl}$ or NGF. Cells were cultured for 48 hr in complete medium containing $40 \mathrm{~mm}$ choline chloride $(A), 45 \mathrm{~mm} \mathrm{KCl}(B)$, or $2 \mathrm{~nm}$ NGF $(C)$ and GAP-43 immunoreactivity was detected by immunofluorescence. Scale bar, 15 $\mu \mathrm{m}$. $D$, Cells were cultured for 24 or $48 \mathrm{hr}$ in choline chloride, $\mathrm{KCl}$, or NGF and GAP-43 immunoreactivity was then detected by Western analysis of cell lysates.

However, unlike $2 \mathrm{nM} \mathrm{NGF,} \mathrm{KCl}$ did not stimulate tyrosine phosphorylation of p140 rks , ERK-1, or ERK-2 (Fig. 3). Therefore depolarization with $\mathrm{K}^{+}$does not activate p140 rikA or ERKs in trkPC12 cells.

trk-PC12 6-24 cells display a basal level of p140 phorylation that is approximately one-fifth that observed in wildtype $\mathrm{PC} 12$ cells treated with maximally effective concentrations (2-4 nM) of NGF, indicating a low level of receptor activation in the absence of added NGF (Hempstead et al., 1992). We investigated whether this low level of constitutive receptor activation was required for the response to depolarization. For these studies we used the kinase inhibitor K252b, which inhibits the tyrosine kinase activity of p140 rike and suppresses basal tyrosine phosphorylation of p140 $0^{\text {rkA }}$ in trk-PC12 cells (Hempstead et al., 1992).

$\mathrm{K} 252 \mathrm{~b}(1 \mu \mathrm{M})$ added during a $24-48 \mathrm{hr}$ period of depolarization with $45 \mathrm{mM} \mathrm{KCl}$ did not inhibit neurite outgrowth (Fig. $4 A$ ). However, trk-PC12 cells pretreated with $1 \mu \mathrm{M} \mathrm{K} 252 \mathrm{~b}$ for 2 weeks failed to extend neurites when subsequently treated with $\mathrm{KCl}$ (Fig. $4 A$ ). This inhibition was only partially reversed by removal of $\mathrm{K} 252 \mathrm{~b}$ just before addition of $\mathrm{KCl}$ (Fig. $4 A$ ). In contrast, K252b added during $24-48 \mathrm{hr}$ of treatment with $2 \mathrm{nM} \mathrm{NGF}$ completely blocked NGF-induced neurite outgrowth (Fig. 4B). In addition, inhibition of NGF-induced neurite formation was rapidly reversed by removal of $\mathrm{K} 252 \mathrm{~b}$ just before addition of
NGF (Fig. 4B). These findings indicate that concurrent NGF receptor activation, while necessary for NGF-induced neurite outgrowth, is not required for $\mathrm{K}^{+}$-induced neurite outgrowth. Instead, cellular changes that develop during chronic, low level NGF receptor activation appear to prepare $t r k-\mathrm{PC} 12$ cells to undergo depolarization-induced neurite outgrowth.

If only a low level of p140 rrkA activation is required for $\mathrm{K}^{+}$induced neurite outgrowth, then treatment with concentrations of NGF insufficient to elicit neurite formation should allow wildtype PC12 cells to grow neurites when depolarized. In previous work, we found that wild-type PC12 cells express neurites only when cultured with concentrations of NGF exceeding $30 \mathrm{pm}$ (Messing et al., 1991). Treatment of wild-type PC12 cells with 20 pM NGF did not elicit neurite growth (data not shown). However, pretreatment with 20 pM NGF potentiated neurite outgrowth induced by $45 \mathrm{~mm} \mathrm{KCl}$ (Fig. 5). This effect was most pronounced when wild-type PC12 cells were exposed to $20 \mathrm{pm}$ NGF for $15 \mathrm{~d}$ before addition of $\mathrm{KCl}$ (Fig. 5) and was comparable to outgrowth observed in trk-PC12 6-24 cells depolarized with $45 \mathrm{~mm} \mathrm{KCl}$ for $24 \mathrm{hr}$ (compare Fig. 5 and Fig. 1D). The enhancement of $\mathrm{KCl}$-induced neurite outgrowth persisted even when NGF was withdrawn from the cultures during the period of depolarization (Fig. $5 B$ ). In contrast, pretreatment with $20 \mathrm{pm}$ NGF did not enhance neurite outgrowth induced by 2 nM NGF (Fig. 5B). These findings support the conclusion that chronic, 

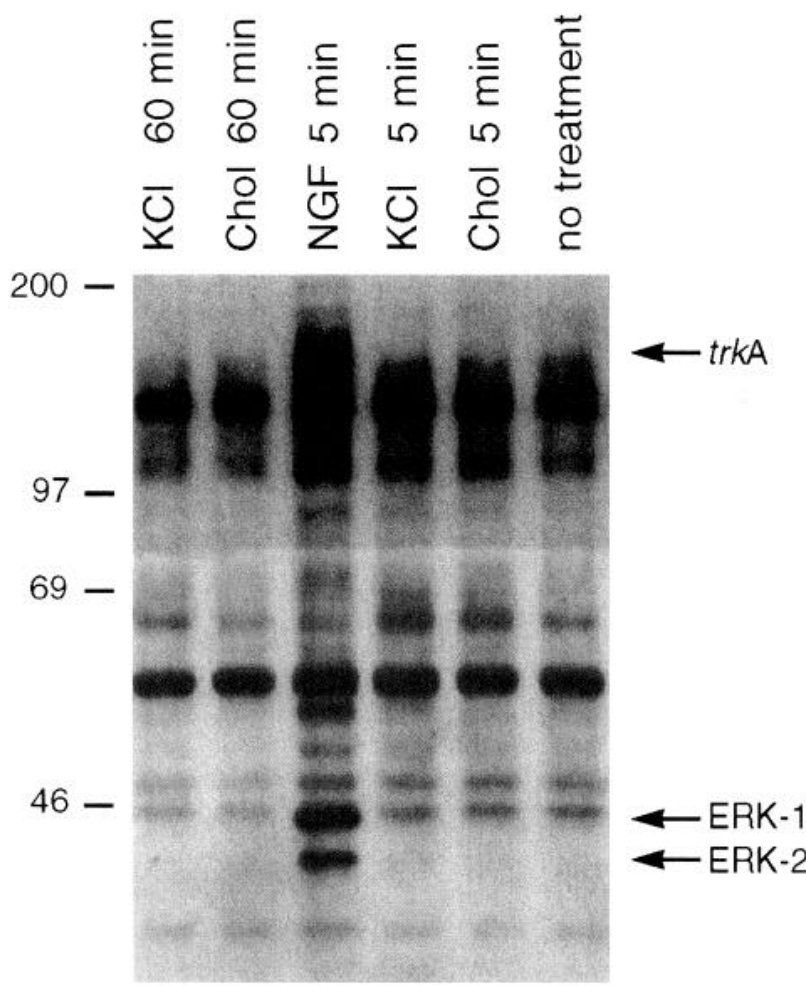

Figure 3. Phosphotyrosine immunoreactivity in trk-PC12 6-24 cells treated with $\mathrm{KCl}$ or NGF. Cells were incubated for indicated times with $40 \mathrm{~mm}$ choline chloride ( $\mathrm{Chol}), 45 \mathrm{~mm} \mathrm{KCl}(\mathrm{KCl})$, or 2 nM NGF $(N G F)$ and then analyzed by Western analysis with anti-phosphotyrosine antibody. Shown is a representative experiment repeated twice with similar results. Note that bands indicated by arrows (trkA, ERK-1, and ERK2) are only present in the NGF-treated sample.

low levels of NGF receptor activation enable cells to undergo depolarization-induced neurite outgrowth.

\section{$\mathrm{Ca}^{2+}$ influx through $\mathrm{L}$ channels is required for depolarization-} induced neurite outgrowth

Elevation of $\left[\mathrm{Ca}^{2+}\right]_{i}$ can promote neurite outgrowth (Kater and Mills, 1991), and in $\mathrm{PCl} 2$ cells depolarization can elevate $\left[\mathrm{Ca}^{2+}\right]$, by stimulating $\mathrm{Ca}^{2+}$ influx through voltage-gated $\mathrm{Ca}^{2+}$ channels (Stallcup, 1979). Therefore, we examined whether depolarization-induced neurite outgrowth required $\mathrm{Ca}^{2+}$ influx through voltage-gated $\mathrm{Ca}^{2+}$ channels.

Depolarization of $\mathrm{PC} 12$ cells causes a rise in $\left[\mathrm{Ca}^{2+}\right]_{i}$ that remains elevated for at least $15 \mathrm{~min}$ (Di Virgilio et al., 1987). To determine whether prolonged exposure to elevated $\mathrm{KCl}$ causes persistent elevation of $\left[\mathrm{Ca}^{2+}\right]_{i}$ in trk-PC12 cells, we measured $\left[\mathrm{Ca}^{2+}\right]_{i}$ with fura-2. $\left[\mathrm{Ca}^{2+}\right]_{i}$ in cells cultured in complete medium was $72 \pm 6 \mathrm{nM}(N=10)$. Treatment with $45 \mathrm{~mm} \mathrm{KCl}$ for 24 hr raised $\left[\mathrm{Ca}^{2+}\right]_{i}$ to $150 \pm 17 \mathrm{nM}(N=13 ; p<0.05$; ANOVA, Scheffe $F$ test). In cells treated with $\mathrm{KCl}$ plus $2 \mathrm{~mm}$ EGTA for $24 \mathrm{hr},\left[\mathrm{Ca}^{2+}\right]_{i}$ was reduced to $21 \pm 3 \mathrm{nM}(N=13 ; p<0.05$ compared to cells cultured in $45 \mathrm{~mm} \mathrm{KCl}$; ANOVA, Scheffe $F$ test). These results indicate that the rise in $\left[\mathrm{Ca}^{2+}\right]_{i}$ induced by $\mathrm{KCl}$ requires external $\mathrm{Ca}^{2+}$.

We next examined whether $\mathrm{K}^{+}$-stimulated neurite outgrowth was inhibited by chelating external $\mathrm{Ca}^{2+}$ or by blocking voltagegated $\mathrm{Ca}^{2+}$ channels. As shown in Figure 6, treatment with EGTA markedly reduced $\mathrm{K}^{+}$-stimulated neurite outgrowth, suggesting that extracellular $\mathrm{Ca}^{2+}$ was necessary for this response.
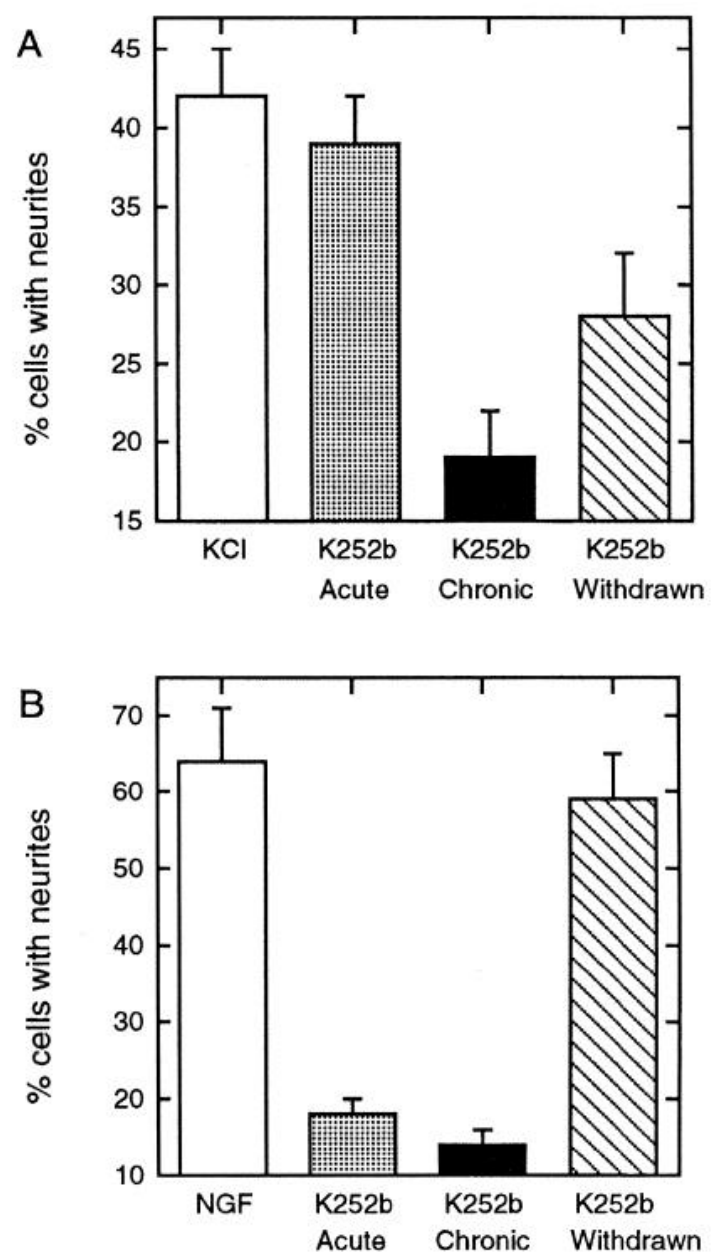

Figure 4. Inhibition of $\mathrm{K}^{+}$- and NGF-induced neurite outgrowth by $\mathrm{K} 252 \mathrm{~b}$ in trk-PC12 6-24 cells. A, Neurite outgrowth was measured in cultures after treatment with $45 \mathrm{~mm} \mathrm{KCl}$ for $48 \mathrm{hr}$. Cells were treated with $\mathrm{KCl}$ alone (Con) or with $\mathrm{KCl}$ plus $1 \mu \mathrm{M} \mathrm{K252b}$ (K252b Acute). Some cells were pretreated with $\mathrm{K} 252 \mathrm{~b}$ for $7 \mathrm{~d}$ before $\mathrm{KCl}$ was added ( $K 252 \mathrm{~b}$ Chronic). In some of these K252b-pretreated cultures, K252b was removed when treatment with $\mathrm{KCl}$ was begun $(K 252 b$ Withdrawn). $B$, Neurite outgrowth was measured in cultures treated for $48 \mathrm{hr}$ with 2 nM NGF instead of $45 \mathrm{~mm} \mathrm{KCl}$. Treatment groups were otherwise similar to those described in $A$.

The L-type $\mathrm{Ca}^{2+}$ channel antagonists nifedipine and verapamil also markedly inhibited $\mathrm{K}^{+}$-stimulated neurite outgrowth. However, blockade of $\mathrm{N}$-type $\mathrm{Ca}^{2+}$ channels with $\omega$-conotoxin GVIA (Wheeler et al., 1994), P-type $\mathrm{Ca}^{2+}$ channels with $\omega$-agatoxin IVA (Wheeler et al., 1994), or T-type $\mathrm{Ca}^{2+}$ channels with ethosuximide (Coulter et al., 1989) did not inhibit neurite formation.

Besides $\mathrm{Ca}^{2+}$ channels, $\mathrm{PC} 12$ cells express receptors and other ion channels that are activated by depolarization and could regulate neurite growth. $\mathrm{PC} 12$ cells possess nicotinic and muscarinic ACh receptors (Messing et al., 1989) and release ACh when depolarized (Greene and Rein, 1977). In frog embryonic spinal neurons, $\mathrm{ACh}$ modulates neurite growth by stimulating turning of growth cones through an L-channel-dependent mechanism (Zheng et al., 1994). However, blockade of muscarinic receptors with atropine or nicotinic receptors with mecamylamine (Messing et al., 1989) did not reduce $\mathrm{K}^{+}$-stimulated neurite outgrowth (Fig. 6), indicating that released $\mathrm{ACh}$ does not mediate the morphogenetic response to depolarization. PC12 cells also express voltage-gated $\mathrm{Na}^{+}$channels (Stallcup, 1979) and blockade of 

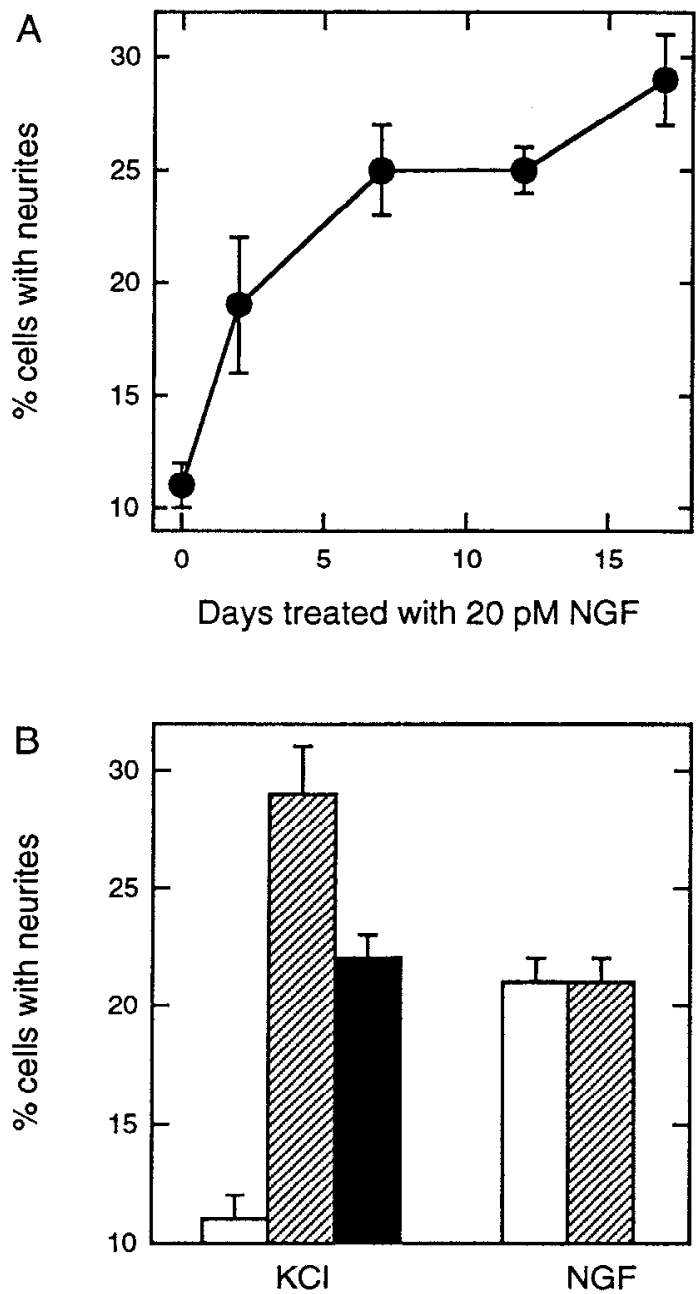

Figure 5. Low-dose NGF treatment enables wild-type PC12 cells to extend neurites in $45 \mathrm{~mm} \mathrm{KCl}$. $A$, Neurite outgrowth was measured in PC1 2 cell cultures treated for $0-17$ d with 20 pM NGF, to which $45 \mathrm{~mm}$ $\mathrm{KCl}$ was added during the last $2 \mathrm{~d}$ of culture. $B$, Neurite outgrowth was compared in PC12 cells pretreated with (hatched bars) or without (open bars) 20 pM NGF for $15 \mathrm{~d}$ before addition of either $45 \mathrm{mM} \mathrm{KCl}$ or 2 nM NGF to the cultures for $48 \mathrm{hr}$. Some cells were pretreated with 20 pM NGF for $15 \mathrm{~d}$ and then the NGF was removed before addition of $45 \mathrm{~mm} \mathrm{KCl}$ for $48 \mathrm{hr}$ (solid bar). Data are mean $\pm \mathrm{SE}$ values from $3-$ 5 experiments.

$\mathrm{Na}^{+}$channels by tetrodotoxin alters neurite growth in cultured cerebellar Purkinje neurons (Schilling et al., 1991). However, 1 $\mu \mathrm{M}$ tetrodotoxin did not reduce $\mathrm{K}^{+}$-stimulated neurite outgrowth (Fig. 6). Therefore, L-type voltage sensitive $\mathrm{Ca}^{2+}$ channels appear to be selectively required for $\mathrm{K}^{+}$-stimulated neurite formation in trk-PC12 cells.

\section{$\mathrm{Ca}^{2+} /$ calmodulin-dependent protein kinase $I I$ is required for $K^{+}$-stimulated neurite outgrowth}

Elevation of intracellular $\mathrm{Ca}^{2+}$ can activate $\mathrm{Ca}^{2+}$-sensitive enzymes that modulate neural growth such as CaM kinase II (Goshima et al., 1993) and certain isozymes of protein kinase C (PKC) (Nishizuka, 1992). Activation of CaM kinase II may be particularly important in neurite outgrowth. For example, overexpression of CaM kinase II in neuroblastoma cell lines stimulates neurite formation (Goshima et al., 1993). In addition, KN62, an inhibitor of CaM kinases II and IV (Tokumitsu et al., 1990; Enslen et al., 1994), reduces neurite outgrowth in rat hip- pocampal neurons cultured in $20 \mathrm{~mm} \mathrm{KCl}$ (Cabell and Audesirk, 1993), and prevents turning of growth cones from isolated Xenopus spinal neurons in response to depolarization by acetylcholine (Zheng et al., 1994).

To investigate the relative roles of $\mathrm{CaM}$ kinases and $\mathrm{PKC}$ in neurite outgrowth, we cultured cells with the CaM kinase inhibitor KN-62 or with bisindolylmaleimide, an inhibitor of PKC (Toullec et al,, 1991). As shown in Figure 7B, KN-62 caused a concentration-dependent reduction in $\mathrm{K}^{+}$-stimulated neurite formation with an $\mathrm{IC}_{50}$ of $1.14 \pm 0.05 \mu \mathrm{M}$, which is similar to the $\mathrm{K}_{\mathrm{i}}$ for inhibition of CaM kinase II $(0.9 \mu \mathrm{M}$; Tokumitsu et al., $1990)$ and the $\mathrm{IC}_{50}$ for inhibition of CaM kinase IV $(0.5-2 \mu \mathrm{M}$; Enslen et al., 1994) in vitro. In contrast, $1 \mu \mathrm{M}$ bisindolylmaleimide, a concentration that maximally inhibits $\mathrm{PKC}$ in vitro (Toullec et al., 1991), did not inhibit $\mathrm{K}^{+}$-stimulated neurite outgrowth $(100 \pm 2 \%$ of neurite outgrowth in trk-PC12 cells treated with $45 \mathrm{~mm} \mathrm{KCl}$ alone after $24 \mathrm{hr}$ ). Contrary to its effects on depolarization-induced neurite outgrowth, KN-62 did not inhibit neurite outgrowth induced by 2 nM NGF $(92 \pm 5 \%$ of neurite outgrowth in trk-PC12 cells treated with NGF alone after $24 \mathrm{hr}$ ).

In addition to inhibiting CaM kinases II and IV, KN-62 inhibits $\mathrm{Ca}^{2+}$ influx through L-type $\mathrm{Ca}^{2+}$ channels (Guodong et al., 1992). To investigate whether blockade of $\mathrm{L}$ channels could account for inhibition of $\mathrm{K}^{+}$-stimulated neurite outgrowth by $\mathrm{KN}$ 62, we examined $\mathrm{K}^{+}$-stimulated ${ }^{45} \mathrm{Ca}^{2+}$ uptake in trk-PC12 6-24 cells. ${ }^{45} \mathrm{Ca}^{2+}$ uptake measured by this technique is completely inhibited by L channel antagonists in PC12 cells (Messing et al., 1985). As shown in Figure $7 A$, nifedipine inhibited $\mathrm{K}^{+}$-stimulated ${ }^{45} \mathrm{Ca}^{2+}$ uptake and neurite outgrowth to a similar extent at all concentrations examined and inhibition was nearly complete with $1 \mu \mathrm{M}$ nifedipine. KN-62 also inhibited $\mathrm{K}^{+}$-stimulated neurite outgrowth in a concentration-dependent fashion and nearly complete inhibition was achieved with $10 \mu \mathrm{M} \mathrm{KN} 62$. However, in contrast to $1 \mu \mathrm{M}$ nifedipine, $10 \mu \mathrm{M} \mathrm{KN}-62$ only partly reduced ${ }^{45} \mathrm{Ca}^{2+}$ uptake by $52 \pm 6 \%$ (Fig. $7 B$ ). This indicates that blockade of $\mathrm{L}$ channels does not fully account for inhibition of neurite outgrowth by $\mathrm{KN}-62$ and suggests that inhibition of CaM kinases is also important.

\section{Depolarization-induced neurite outgrowth is transcription dependent}

Initiation of neurite outgrowth by NGF in wild-type PC 12 cells requires gene transcription since it is blocked by transcription inhibitors (Greene et al., 1982). To investigate whether depolarization-induced neurite outgrowth in $t r k$-PC12 cells is transcription dependent, we cultured cells in $45 \mathrm{mM} \mathrm{KCl}$ in the presence or absence of $0.01 \mu \mathrm{g} / \mathrm{ml}$ of actinomycin $\mathrm{D}$ or $20 \mu \mathrm{M}$ of cordycepin. As shown in Table 1 , exposure to either transcription inhibitor markedly reduced $\mathrm{K}^{+}$-stimulated neurite outgrowth.

\section{Discussion}

A major finding of this article is that low levels of NGF receptor stimulation, inadequate for ordinary receptor activation and neurite outgrowth, exert a permissive effect enabling PC12 cells to express neurites when depolarized. Such permissive levels of NGF receptor stimulation could be induced by overexpression of $\mathrm{p} 140^{r k A}$ or by treatment of wild-type PC12 cells with a low concentration ( $20 \mathrm{pM}$ ) of NGF. In both cases, the degree of receptor activation was insufficient to elicit neurite outgrowth alone.

These findings are similar to those reported by Koike (Koike, 1986) who found that depolarization with $\mathrm{KCl}$ enhanced NGF- 


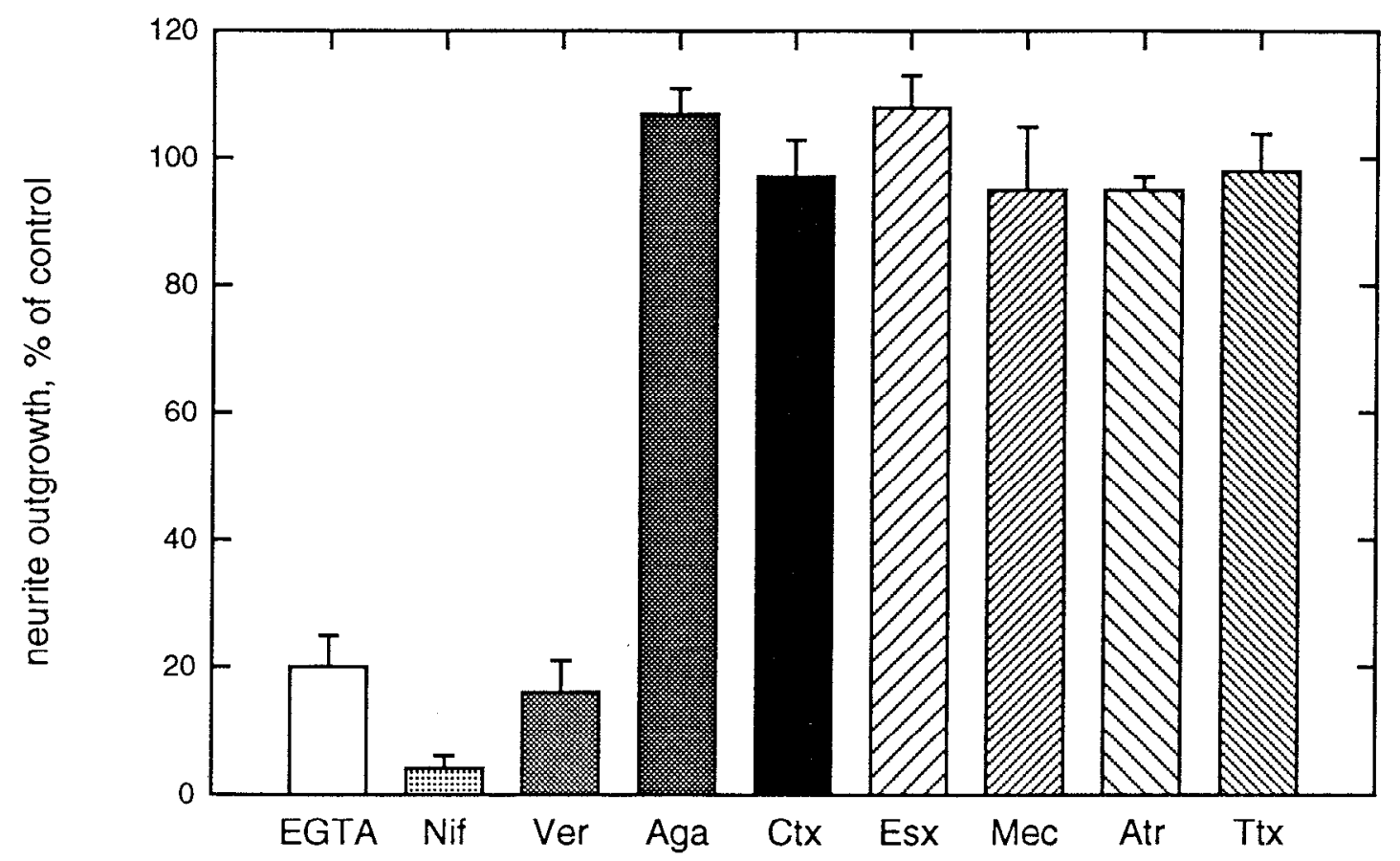

Figure 6. $\mathrm{K}^{+}$-induced neurite outgrowth in trk-PC12 6-24 cells cultured with EGTA or various channel and receptor antagonists. Cells were cultured in 2 mM EGTA (EGTA), $1 \mu \mathrm{M}$ nifedipine (Nif), $10 \mu \mathrm{M}$ verapamil (Ver), $200 \mathrm{nM}$ w-agatoxin IVA (Aga), $1 \mu \mathrm{M} \omega$-conotoxin GVIA (Ctx), $500 \mu \mathrm{M}$ ethosuximide $(E S x), 10 \mu \mathrm{m}$ mecamylamine $(\mathrm{Mec}), 100 \mathrm{nM}$ atropine (Atr), or $1 \mu \mathrm{M}$ tetrodotoxin (Ttx). Data are mean \pm SE values from 2-4 experiments.

induced neurite outgrowth. He proposed that this was due to an increase in binding of NGF to NGF receptors in depolarized cells. However, we found that depolarization did not stimulate phosphorylation of trkA or of ERK-1 and ERK-2 MAP kinases in trk-PC12. cells. In addition, simultaneous treatment of trk$\mathrm{PC} 12$ cells with $45 \mathrm{mM} \mathrm{KCl}$ and the trkA inhibitor $\mathrm{K} 252 \mathrm{~b}$ did not inhibit depolarization-induced neurite outgrowth. Instead, it was necessary to pretreat cells with $\mathrm{K} 252 \mathrm{~b}$ for several days prior to depolarization to inhibit neurite formation. Moreover, pretreatment with 20 pM NGF for several days enabled wild-type PC12 cells to grow neurites when depolarized. This capacity for depolarization-induced neurite outgrowth persisted when NGF was removed during a $48 \mathrm{hr}$ period of depolarization. These results indicate that depolarization does not promote NGF-induced signal transduction and depolarization-induced neurite outgrowth does not require simultaneous stimulation of NGF receptors. Instead, depolarization-induced neurite outgrowth requires permissive cellular changes induced by prior long-term, low level NGF receptor activation.

Saffell et al. (Saffell et al., 1992) reported that wild-type PC12 cells cultured on a monolayer of 3 T3 fibroblasts extend neurites when depolarized with $\mathrm{KCl}$. Low level NGF receptor activation may also be involved in depolarization-induced neurite outgrowth in these cultures, since neurite outgrowth was inhibited by coadministration of K252b (Saffell et al., 1992), and 3T3 cells and other fibroblasts secrete NGF (Hattori et al., 1993). Based on our present results, it is likely that low levels of NGF secreted by the $3 \mathrm{~T} 3$ cell monolayer enabled overlying PC12 cells to undergo depolarization-induced neurite outgrowth. It would be of interest to know whether antibodies to NGF prevent depolarization-induced neurite outgrowth in this culture system.

The second major finding of our study is that in addition to permissive NGF receptor stimulation, depolarization-induced neurite outgrowth in PC12 cells requires influx of extracellular
$\mathrm{Ca}^{2+}$ through $\mathrm{L}$ type $\mathrm{Ca}^{2+}$ channels and activation of CaM kinase II or IV. Chelation of extracellular $\mathrm{Ca}^{2+}$ with EGTA, or blockade of $\mathrm{L}$ channels with nifedipine or verapamil prevented depolarization-induced neurite outgrowth. The CaM kinase inhibitor KN-62 also prevented neurite outgrowth. Inhibition of neurite outgrowth by KN-62 is only partly due to inhibition of $L$ channels, since $10 \mu \mathrm{M} \mathrm{KN}-62$, which almost completely inhibited neurite outgrowth, had much less of an effect on $\mathrm{K}^{+}$-stimulated ${ }^{45} \mathrm{Ca}^{2+}$ uptake (Fig. $7 B$ ). In contrast, $1 \mu \mathrm{M}$ nifedipine, which inhibited $\mathrm{K}^{+}$-stimulated ${ }^{45} \mathrm{Ca}^{2+}$ uptake almost completely, was required to maximally inhibit $\mathrm{K}^{+}$-stimulated neurite outgrowth (Fig. 7A). Therefore, partial L channel blockade can not entirely explain the inhibitory effect of KN-62 on depolarization-induced neurite outgrowth. Instead, these data support a role for $\mathrm{CaM}$ kinase II or IV in mediating this process.

The mechanism by which low level NGF receptor stimulation enables cells to respond to depolarization is not known. $\mathrm{L}$ channel antagonist binding and $\mathrm{L}$ channel function are increased 33 $80 \%$ by treatment for $4 \mathrm{~d}$ with high concentrations ( $2 \mathrm{nM}$ ) of NGF that maximally activate NGF receptors (Usowicz et al., 1990). Similar NGF treatment increases expression of calmodulin in PC12 cells by about threefold (Bai and Weiss, 1991). If levels of $[\mathrm{Ca}]_{i}$ or free calmodulin are rate-limiting for $\mathrm{CaM}$ kinase activation during depolarization, increases in $\mathrm{L}$ channels or calmodulin induced by low concentrations of NGF could increase CaM kinase activity in depolarized wild-type PC 12 cells. In addition, several cytoskeletal proteins, enzymes, and cell-surface glycoproteins that regulate neurite outgrowth are induced by treatment with 2 nM NGF (Greene, 1984) and increased expression of some of these proteins may occur with low level NGF receptor stimulation. For example, trk-PC12 cells express elevated levels of the protease transin and the secretory granule protein VGF (Hempstead et al., 1992). High concentrations of NGF (2-4 nM) also stimulate the phosphorylation of several pro- 

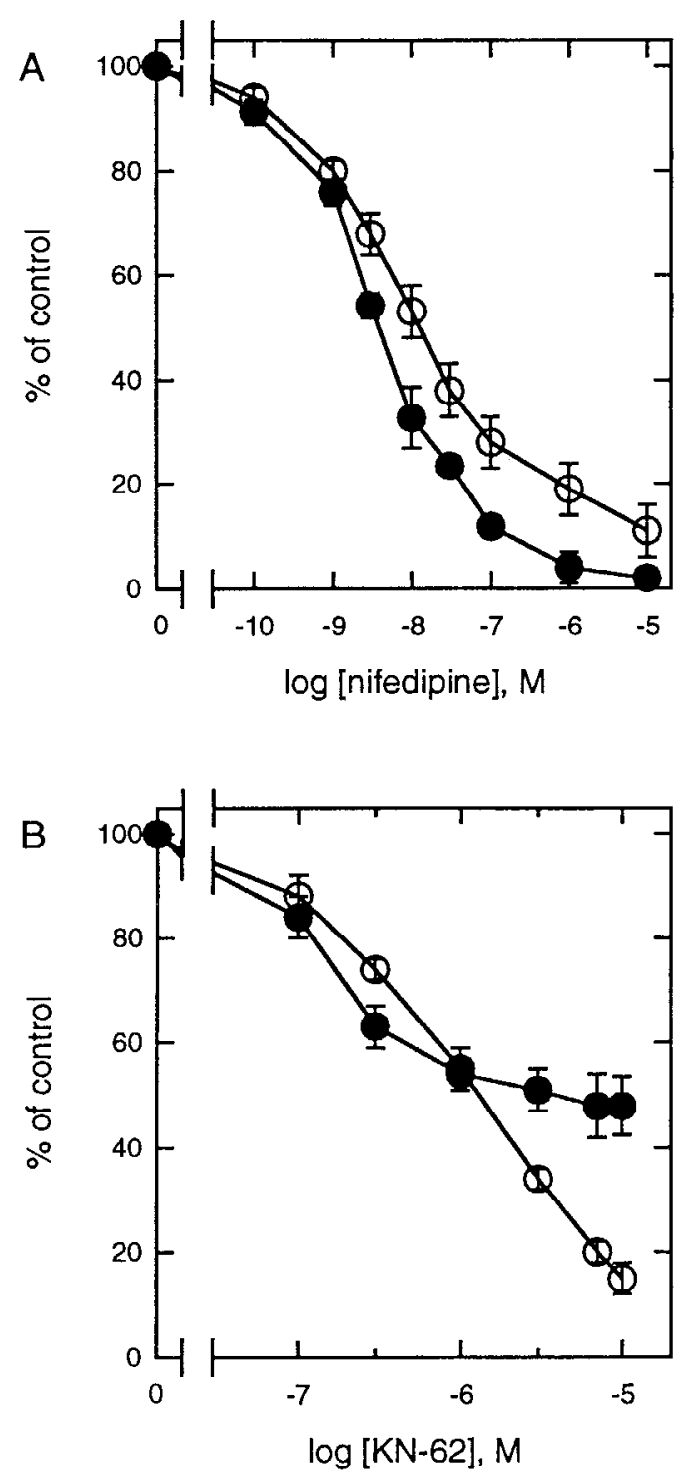

Figure 7. Inhibition of $\mathrm{K}^{+}$-induced ${ }^{45} \mathrm{Ca}^{2+}$ uptake and neurite outgrowth by nifedipine and KN-62 in trk-PC12 6-24 cells. Neurite outgrowth (open circles) was measured after cells were cultured for $24 \mathrm{hr}$ in $45 \mathrm{mM} \mathrm{KCl}$ plus indicated concentrations of nifedipine $(A)$ or $\mathrm{KN}$ $62(B) . \mathrm{KCl}$-stimulated ${ }^{45} \mathrm{Ca}^{2+}$ uptake (solid circles) was measured in cultures preincubated for $25 \mathrm{~min}$ and then depolarized for $2.5 \mathrm{~min}$ in indicated concentrations of nifedipine $(A)$ or KN-62 $(B)$. Data are mean $\pm \mathrm{SE}$ values from 3 (neuritc outgrowth) or $4-6\left({ }^{45} \mathrm{Ca}^{2+}\right.$ uptake) experiments.

teins important for neurite structure and growth (Halegoua, 1987; Lindenbaum et al., 1987; Aletta et al., 1988; Aletta et al., 1989). It is not known whether any of these are phosphorylated with low levels of $\mathrm{NGF}$ receptor stimulation.

Depolarization-induced neurite outgrowth not only involves activation of $\mathrm{L}$ channcls and CaM kinases, but also requires gene transcription since it was inhibited by actinomycin D and cordycepin. Depolarization could activate gene expression by activating CaM kinase II or IV which phosphorylate the transcription factor CREB (Hunter and Karin, 1992; Enslen et al., 1994). In addition to regulating gene expression, CaM kinase II phosphorylates several cytoskeletal proteins such as tau, MAP-2, and neurofilament proteins (Hanson and Schulman, 1992). Phosphorylation of MAP-2 by CaM kinase II inhibits its ability to

\begin{tabular}{lcc}
\hline $\begin{array}{l}\text { Table 1. Inhibition of } \mathrm{K}^{+} \text {-induced neurite outgrowth by } \\
\text { transcription inhibitors }\end{array}$ & \\
& $\begin{array}{l}\text { \% Cells with } \\
\text { neurites }\end{array}$ & $N$ \\
\hline Treatment & $6 \pm 1$ & 8 \\
\hline $40 \mathrm{mM} \mathrm{choline} \mathrm{Cl}$ & $39 \pm 2$ & 8 \\
$45 \mathrm{mM} \mathrm{KCl}$ & $10 \pm 1^{\prime \prime}$ & 4 \\
$45 \mathrm{mM} \mathrm{KCl}+20 \mu \mathrm{M} \mathrm{cordycepin}$ & $6 \pm 1^{\prime \prime}$ & 6 \\
$45 \mathrm{mM} \mathrm{KCl}+0.01 \mu \mathrm{g} / \mathrm{ml}$ actinomycin D &
\end{tabular}

trk-PC12 6-24 cells were cultured in poly-L-ornithine-treated tissue culture dishes for $24 \mathrm{hr}$ in the indicated agents and neurite outgrowth was scored as described in Materials and Methods.

"Effects were significantly different from choline control at greater than $95 \%$ confidence limits by ANOVA and Scheffe $F$ test.

${ }^{b}$ Effects were significantly different from $\mathrm{KCl}$-treated cultures at greater than $95 \%$ confidence limits by ANOVA and Scheffe $F$ test.

stimulate microtubule assembly (Yamauchi and Fujisawa, 1983; Yamamoto et al., 1985), and cross-linking of actin filaments (Yamauchi and Fujisawa, 1988). 'I'herefore, activation of these CaM kinases could induce neurite outgrowth by regulating gene expression and the function of cytoskclctal protcins.

Recently, depolarization was reported to cause transient activation of ERK-1 and ERK-2 in wild-type PC12 cells (Rosen et al., 1994). This could also induce gene expression since MAP kinases regulate several transcription factors (Davis, 1993). However, we found that depolarization did not stimulate tyrosine phosphorylation of ERK-1 or ERK-2 in trk-PC12 cells (see Fig. 3). Since tyrosine phosphorylation of MAP kinases is required for their activation (Anderson et al., 1990), our result indicates that depolarization does not activate ERK-1 and ERK-2 in trkPC12 cells. The discrepancy between our finding and that of Rosen et al. (Rosen et al., 1994) may be explained by differences in PC12 cell lines. Alternatively, chronic, low level NGF receptor stimulation in trk-PC12 cells may have desensitized cells to depolarization-induced activation of MAP kinases. In any case, our results suggest that there are at least two separate pathways for ncuritc outgrowth in PC12 cells: one stimulated by high concentrations of NGF that maximally activate NGF receptors and cause sustained activation of MAP kinases; and another stimulated by depolarization, requiring $\mathrm{Ca}^{2+}$ influx through $\mathrm{L}$ channels, CaM kinase activation, and low, permissive levels of NGF receptor stimulation.

Depolarization prevents neurite degeneration after NGF withdrawal in PC12 cells (Teng and Greene, 1993) and stimulates rapid sprouting of filopodia from established growth cones in PC12 cells, adrenal chromaffin cells, and rat dorsal root ganglion neurons (Manivannan and Terakawa, 1994). In PC12 cells, depolarization also maintains NGF-induced phosphorylation of several proteins ( $\beta$-tubulin, MAP $1.2 / 1 \mathrm{~B}$, and 64 and $72 \mathrm{kDa}$ chartins) and NGF-stimulated increases in MAP 1.2/1B, peripherin, and NILE/L1 glycoprotein (Teng and Greene, 1993). Stabilization of NGF-deprived neurites is inhibited by L channel antagonists (Teng and Greene, 1993), whereas filopodia extension is abolished by chelating extracellular $\mathrm{Ca}^{2+}$ or blocking $\mathrm{Ca}^{2+}$ channels with $\mathrm{La}^{3+}$ (Manivannan and Terakawa, 1994), indicating that both processes require influx of $\mathrm{Ca}^{2+}$ through voltage-gated $\mathrm{Ca}^{2+}$ channels. This requirement for $\mathrm{Ca}^{2+}$ influx suggests that mechanisms similar to those we find involved in depolarization-induced neurite outgrowth may also mediate these other depolarization-induced responses. However, it is not yet known if activation of CaM kinases and gene expression is re- 
quired for depolarization-induced filipodia extension or mainte nance of neurites.

Teng and Greene (1993) found that, in contrast to preserving preexisting neurites, depolarization does not stimulate regeneration of neurites from wild-type PC12 cells primed in $50 \mathrm{ng} / \mathrm{ml}$ of NGF for $10 \mathrm{~d}$. This appears to conflict with our finding that pretreatment of wild-type PC12 cells with 20 pM NGF permits subsequent depolarization-induced neurite outgrowth. However, Saffell et al. (1992) reported that primed PC12 cells express neurites when replated in depolarizing medium on a collagencoated substratum. We considered whether differences in methodology or cell lines accounted for the differences between our results and those of Teng and Greene. We primed our line of wild-type PC12 cells for $7 \mathrm{~d}$ in $50 \mathrm{ng} / \mathrm{ml}$ of NGF and then replated cells on collagen-coated dishes in medium containing $45 \mathrm{~mm} \mathrm{KCl}$. After $48 \mathrm{hr}, 26 \pm 1 \%$ of depolarized, primed cells expressed neurites, whereas only $4 \pm 1 \%$ of primed cells replated in nondepolarizing control medium containing $40 \mathrm{~mm}$ choline chloride exhibited neurite outgrowth $(p<0.003, N=$ 3 ; paired $t$ test). Therefore, our results agree with those of Saffel et al. and disagree with those of Teng and Greene. This may reflect differences in our PC12 cell lines and suggests that some of the mechanisms required for depolarization-induced neurite outgrowth are not involved in depolarization-mediated stabilization of preexisting neurites.

Previous studies have emphasized how depolarization may promote neurite outgrowth by upregulating neurotrophic factors or their receptors. Our results indicate a different interaction between growth factors and depolarization, whereby low levels of neurotrophic factor receptor activation can enable cells to grow neurites when subsequently depolarized. This permissive effect may partly explain why activity-dependent neurite growth occurs in later stages of neural development (Goodman and Shatz, 1993), since the capacity for activity-dependent growth may require prior exposure to growth factors. In addition, these results indicate a mechanism by which neuronal activity can critically alter the growth of neurons exposed to subthreshold concentrations of growth factors. This novel mechanism may not only be important in activity-dependent growth of dendrites and axons during development, but also may contribute to pathological sprouting of neural processes and synaptic reorganization in the brain after multiple seizures and other forms of neural injury.

\section{References}

Adams JC, Gullick WJ (1989) Differences in phorbol-ester-induced down-regulation of protein kinase $\mathrm{C}$ between cell lines. Biochem $\mathrm{J}$ 257:905-911.

Aletta JM, Lewis SA, Cowan NJ, Greene LA (1988) Nerve growth factor regulates both the phosphorylation and steady-state levels of microtubule-associated protein 1.2 (MAP1.2). J Cell Biol 106:15731581.

Aletta JM, Shelanski ML, Greene LA (1989) Phosphorylation of the peripherin 58-kDA neuronal intermediate filament protcin. J Biol Chem 264:4619-4627.

Anderson NG, Maller JL, Tonks NK, Sturgill TW (1990) Requirement for integration of signals from two distinct phosphorylation pathways for activation of MAP kinase. Nature 343:651-653.

Anglister L, Farber IC, Shahar A, Grinvald A (1982) Localization of voltage-sensitive calcium channels along developing neurites: their possible role in regulating neurite elongation. Dev Biol 94:351-365.

Bai G, Weiss B (1991) The increase of calmodulin in PC12 cells induced by NGF is caused by differential expression of multiple mRNAs for calmodulin. J Cell Physiol 149:414-421.

Baker RE, Ruijter JM, Bingmann D (1991) Elevated potassium prevents neuronal death but inhibits network formation in neocortical cultures. Int J Dev Neurosci 9:339-345.
Randtlow CE, Schmidt MF, Hassinger TD, Schwab MF, Kater SB (1993) Role of intracellular calcium in NI-35-evoked collapse of neuronal growth cones. Science 259:80-83.

Bär PR, Renkema GH, Veraart CM, Hol EM, Gispen WH (1993) Nimodipine protects cultured spinal cord neurones from depolarizationinduced inhibition of neurite growth. Cell Calcium 14:293-299.

Berridge MJ (1993) Inositol trisphosphate and calcium signalling. Nature 361:315-325.

Birren SJ, Verdi JM, Anderson DJ (1992) Membrane depolarization induces p140trk and NGF responsiveness, but not $\mathrm{p} 75^{\mathrm{LNGFR}}$, in $\mathrm{MAH}$ cells. Science 257:395-397.

Boulton TG, Nye SH, Robbins DJ, Ip NY, Radziejewska E, Morgenbesser SD, DePinho RA, Panayotatos N, Cobb MH, Yancopoulos GD (1991) ERKs: a family of protein-serine/threonine kinases that are activated and tyrosine phosphorylated in response to insulin and NGF. Cell 65:663-675.

Cabell L, Audesirk G (1993) Effects of selective inhibition of protein kinase $\mathrm{C}$, cyclic AMP-dependent protein kinase, and $\mathrm{Ca}^{2+}$-calmodulin-dependent kinase on neurite development in cultured rat hippocampal neurons. Int J Dev Neurosci 11:357-368.

Cohan CS (1992) Depolarization-induced changes in neurite elongation and intracellular $\mathrm{Ca}^{2+}$ in isolated Helisoma neurons. J Neurobiol 23: 983-996.

Coulter DA, Huguenard JR, Prince DA (1989) Characterization of ethosuximide reduction of low-threshold calcium current in thalamic neurons. Ann Neurol 25:582-593.

Davis RJ (1993) The mitogen-activated protein kinase signal transduction pathway. J Biol Chem 268:14553-14556.

Di Virgilio F, Milan D, Leon A, Meldolesi J, Pozzan T (1987) Voltagedependent activation and inactivation of calcium channels in PC12 cells. J Biol Chem 262:9189-9195.

Enslen H, Sun P, Brickey D, Soderling SH, Klamo E, Soderling T (1994) Characterization of $\mathrm{Ca}^{2+} /$ calmodulin-dependent protein kinase IV. J Biol Chem 269:15520 15527.

Ghosh A, Carnahan J, Greenberg ME (1994) Requirement for BDNF in activity-dependent survival of cortical neurons. Science 263:16181623.

Goodman CS, Shatz CJ (1993) Developmental mechanisms that generate precise patterns of neuronal connectivity. Neuron 72:77-98.

Goshima Y, Ohsako S, Yamauchi T (1993) Overexpression of $\mathrm{Ca}^{2+} /$ calmodulin-dependent protein kinase II in neuro2a and NG10815 neuroblastoma cell lines promotes neurite outgrowth and growth cone motility. J Neurosci 13:559-567.

Greene LA (1984) The importance of both early and delayed responses in the biological actions of nerve growth factor. Trends Neurol Sci 7:91-94.

Greene LA, Rein G (1977) Synthesis, storage and release of acetylcholine by a noradrenergic pheochromocytoma cell line. Nature 268: 349-351.

Greene LA, Burstein DE, Black MM (1982) The role of transcriptiondependent priming in nerve growth factor promoted neurite outgrowth. Dev Biol 91:305-316.

Grynkiewicz G, Poenie M, Tsien RY (1985) A new generation of $\mathrm{Ca}^{2+}$ indicators with greatly improved fluorescence properties. J Biol Chem 260:3440-3450.

Guodong L, Hidaka H, Wollheim CB (1992) Inhibition of voltagegated $\mathrm{Ca}^{2+}$ channels and insulin secretion in HIT cells by the $\mathrm{Ca}^{2+} /$ calmodulin-dependent protein kinase II inhibitor KN-62: comparison with antagonists of calmodulin and $\mathrm{L}$-type $\mathrm{Ca}^{2+}$ channels. Mol Pharmacol 42:489-498.

Halegoua S (1987) Changes in the phosphorylation and distribution of vinculin during nerve growth factor induced neurite outgrowth. Dev Biol 121:97-104.

Hanson PI, Schulman H (1992) Neuronal $\mathrm{Ca}^{2+} /$ calmodulin-dependent protein kinases. Annu Rev Biochem 61:559-601.

Hattori A, Tanaka E, Murase K, Ishida N, Chatani Y, Tsujimoto M, Hayashi K, Kohno M (1993) Tumor necrosis factor stimulates the synthesis and secretion of biologically active nerve growth factor in non-neuronal cells. J Biol Chem 268:2577-2582.

Hempstead BL, Rabin SJ, Kaplan L, Reid S, Parada LF, Kaplan DR (1992) Overexpression of the trk tyrosine kinase rapidly accelerates nerve growth factor-induced differentiation. Neuron 9:883-896.

Hofmann F, Biel M, Flockerzi V (1994) Molecular basis for $\mathrm{Ca}^{2+}$ channel diversity. Annu Rev Neurosci 17:399-418. 
Hunter T, Karin M (1992) The regulation of transcription by phosphorylation. Cell 70:375-387.

Kaplan DR, Martin-Zanca D, Parada LF (1991) Tyrosine phosphorylation and tyrosine kinase activity of the trk proto-oncogene product induced by NGF. Nature 350:158-160.

Kater SB, Mills LR (1991) Regulation of growth cone behavior by calcium. J Neurosci 11:891 899.

Koike T (1986) Potentiation of nerve growth factor (NGF)-mediated neurite outgrowth in high $\mathrm{K}^{+}$medium is associated with increased binding of iodinated NGF in PCl2 cells. Cell Biol Int Rep 10:979984.

Lankford KL, Letourneau PC (1991) Roles of actin filaments and three second-messenger systems in short-term regulation of chick dorsal root ganglion neurite outgrowth. Cell Motil Cytoskeleton 20:7-29.

Lindenbaum MH, Carbonetto S, Mushynski WE (1987) Nerve growth factor enhances the synthesis, phosphorylation, and metabolic stability of neurofilament proteins in PCl2 cells. J Biol Chem 262:605610.

Manivannan S, Terakawa S (1994) Rapid sprouting of filopodia in nerve terminals of chromaffin cells, PCI 2 cells, and dorsal root neurons induced by electrical stimulation. J Neurosci 14:5917-5928.

Mayer ML, Miller RJ (1990) Excitatory amino acid receptors, second messengers and regulation of intracellular $\mathrm{Ca}^{2+}$ in mammalian neurons. Trends Pharmacol Sci 11:254-260.

McNamara JO (1994) Cellular and molecular basis of epilepsy. J Neurosci 14:3413-3425.

Messing RO, Carpenter CL, Greenberg DA (1985) Mechanism of calcium channel inhibition by phenytoin: comparison with classical calcium channel antagonists. J Pharmacol Exp Ther 235:407-411.

Messing RO, Stevens AM, Kiyasu E, Sneade AB (1989) Nicotinic and muscarinic agonists stimulate rapid protein kinase $\mathrm{C}$ translocation in PC1 2 cells. J Neurosci 9:507-512.

Messing RO, Sneade AB, Savidge B (1990) Protein kinase C participates in up-regulation of dihydropyridine-sensitive calcium channels by ethanol. J Neurochem 55:1383-1389.

Messing RO, Henteleff M, Park JJ (1991) Ethanol enhances growth factor-induced neurite formation in PC12 cells. Brain Res 565:301311.

Nishi R, Berg DK (1981) Effects of high $\mathrm{K}^{+}$concentrations on the growth and development of ciliary ganglion neurons in cell culture. Dev Biol 87:301-307.

Nishizuka Y (1992) Intracellular signaling by hydrolysis of phospholipids and activation of protein kinase C. Science 258:607-614.

Rogers M, Hendry I (1990) Involvement of dihydropyridine-sensitive calcium channels in nerve growth factor-dependent neurite outgrowth by sympathetic neurons. J Neurosci $26: 447-454$.

Rosen LB, Ginty DD, Weber MJ, Greenberg ME (1994) Membrane depolarization and calcium influx stimulate MEK and MAP kinase via activation of Ras. Neuron 12:1207-1221.

Saffell JL, Walsh FS, Doherty P (1992) Direct activation of second messenger pathways mimics cell adhesion molecule-dependent neurite outgrowth. J Cell Biol 118:663-670.
Schilling K, Dickinson MH, Connor JA, Morgan JI (1991) Electrical activity in cerebellar cultures determines Purkinje cell dendritic growth patterns. Neuron 7:891-902.

Silver RA, Lamb AG, Bolsover SR (1990) Calcium hotspots caused by L-channel clustering promote morphological changes in neuronal growth cones. Nature 343:751-754.

Stallcup W (1979) Sodium and calcium fluxes in a clonal nerve cell line. J Physiol (Lond) 286:525-540.

Teng KK, Greene LA (1993) Depolarization maintains neurites and priming of PC12 cells after nerve growth factor withdrawal. J Neurosci $13: 3124-3135$.

Thomas SM, DeMarco M, D'Arcangelo G, Halegoua S, Brugge JS (1992) Ras is essential for nerve growth factor- and phorbol esterinduced tyrosine phosphorylation of MAP kinases. Cell 68:10311040.

Tokumitsu H, Chijiwà T, Hagiwara M, Mizutani A, Terasawa M, Hidaka $\mathrm{H}$ (1990) KN-62, 1-[N,O-Bis(5-isoquinolinesulfonyl)- $N$-methyl-Ltyrosyl]-4-phenylpiperazine, a specific inhibitor of $\mathrm{Ca}^{2+} / \mathrm{calmodulin}$ dependent protein kinase II. J Biol Chem 265:4315-4320.

Toullec D, Pianetti P, Coste H, Bellevergue P, Grand-Perret T, Ajakane $M$, Baudet V, Boissin P, Boursier E, Loriolle $F$, Duhamel $L$, Charon D, Kirilovsky J (1991) The bisindolylmaleimide GF 109203X is a potent and selective inhibitor of protein kinase C. J Biol Chem 266: 15771-15781.

Unsicker K, Hofmann H-D, Höhne I, Müller TH, Schmidt R (1983) Phenotypic plasticity of cultured bovine chromaffin cells. II. Fiber outgrowth induced by elevaled potassium: morphology and ionic requirements. Dev Brain Res 9:369-379.

Usowicz MM, Porzig H, Becker C, Reuter H (1990) Differential expression by nerve growth factor of two types of $\mathrm{Ca}^{2+}$ channels in rat phaeochromocytoma cell lines. J Physiol (Lond) 426:95-116.

Wheeler DB, Randall A, Tsien RW (1994) Roles of N-type and Q-type $\mathrm{Ca}^{2+}$ channels in supporting hippocampal synaptic transmission. Science 264:107-111.

Williams DA. Fay FS (1990) Intracellular calibration of the fluorescent calcium indicator Fura-2. Cell Calcium 11:75-83.

Wood KW, Sarnecki C, Roberts TM, Blenis J (1992) ras mediates nerve growth factor receptor modulation of three signal-transducing protein kinases: MAP kinase, Raf-1, and RSK. Cell 68:1041-1050.

Yamamoto H, Fukunaga K, Goto S, Tanaka E, Miyamoto E (1985) $\mathrm{Ca}^{2+}$, calmodulin-dependent regulation of microtubule formation via phosphorylation of microtubule-associated protein $1, \tau$ factor, and tubulin, and comparison with the cyclic AMP-dependent phosphorylation. J Neurochem 44:759-768.

Yamauchi T, Fujisawa H (1983) Disassembly of microtubules by the action of calmodulin-dependent protein kinase (kinase II) which occurs only in the brain tissues. Biochem Biophys Res Commun 110: 287-291.

Yamauchi T, Fujisawa $H$ (1988) Regulation of the interaction of actin filaments with microtubule-associated protein 2 by calmodulin-dependent protein kinase II. Biochim Biophys Acta 968:77-85.

Zheng JQ, Felder M, Connor JA, Poo M-M (1994) Turning of nerve growth cones induced by neurotransmitters. Nature 368:140-144. 